Alexander Martin Juranek

\title{
Międzynarodowa harmonizacja prawa prywatnego na przykładzie wybranych aktów modelowego prawa umów w zakresie regulacji kary umownej
}

\author{
International harmonisation of private law on the example of selected \\ acts of a model contract law regarding the regulation of contractual \\ penalty
}

\begin{abstract}
The purpose of this article is to synthesize the basic acts of the so-called model contract law and the relations between the solutions adopted in them and the regulation of contractual penalty applicable in Polish law. Particular emphasis was puted on the analysis of conditions for a claim for payment of a contractual penalty and acceptable limits of modification of a debtor's liability in Polish and model law. On the basis of model law, it was proposed to resolve the most frequent doubts in Polish doctrine. The comparative conclusions drawn in relation to the contractual penalty are also an example of evaluation of the Polish regulation from the point of view of the progressing process of European private law harmonisation.
\end{abstract}

Keywords: harmonisation, private law, model law, civil law, stipulated payment, contractual penalties, contractual liability, breach of contract, limits of liability

Niniejszy artykuł ma na celu syntetyczne przybliżenie podstawowych aktów tzw. modelowego prawa umów oraz relacji pomiędzy przyjętymi w nich rozwiązaniami a obowiązującą w prawie polskim regulacją kary umownej. Szczególny nacisk położono na analizę przesłanek powstania roszczenia o zapłatę kary umownej i dopuszczalnych granic modyfikacji odpowiedzialności dłużnika w prawie polskim i modelowym. W oparciu o prawo modelowe zaproponowano rozstrzygnięcie najczęściej pojawiających się wątpliwości w polskiej doktrynie. Wyprowadzone wnioski komparatystyczne w odniesieniu do kary umownej stanowią nadto przykład oceny polskiej regulacji z punktu widzenia postępującego procesu europejskiej harmonizacji prawa prywatnego.

Słowa kluczowe: harmonizacja, prawo prywatne, prawo modelowe, prawo cywilne, kara umowna, odpowiedzialność kontraktowa, naruszenie umowy, granice odpowiedzialności

\section{Doktorant -}

Uniwersytet Warszawski, Wydział Prawa i Administracji, WARSZAWA, POLSKA •

Uniwersytet Śląski w Katowicach, Instytut Nauk Prawnych, Zespół badawczy ds. prawa

cywilnego i prawa prywatnego międzynarodowego, KATOWICE, POLSKA -

am.juranek@wpia.uw.edu.pl • https://orcid.org/0000-0002-4927-8252

\section{Uwagi wprowadzające}

Od wielu lat w europejskiej doktrynie toczy się dyskusja o potrzebie utworzenia kompleksowej jednolitej regulacji, która stanowiłaby spójne ramy współpracy między państwami europejskimi w obszarze prawa prywatnego, zapewniając 
możliwą jednolitość i spójność funkcjonujących mechanizmów i rozwiązań. Celem niniejszego artykułu jest, po pierwsze, wskazanie, o jakie regulacje akcentujące tę „jednolitość” chodzi, a po drugie - praktyczne przedstawienie relacji między konstrukcjami tego prawa (tzw. prawa modelowego) a ich funkcjonalnymi odpowiednikami w prawie krajowym.

Warto przypomnieć, że szczególnie doniosłe (i niejako pionierskie) znaczenie w płaszczyźnie wspólnotowych projektów kodyfikacji prawa prywatnego w szczególności prawa umów - odegrała Konwencja Narodów Zjednoczonych o umowach międzynarodowej sprzedaży towarów ${ }^{1}$, sporządzona w Wiedniu 11 kwietnia 1980 r. $^{2}$, a stosowana do dziś przez większość państw członkowskich UE. To właśnie jej rozwiązania zostały w większym lub mniejszym stopniu recypowane w procesie późniejszego konstruowania podwalin europejskiego prawa umów ${ }^{3}$, stanowiąc odpowiedź na wysnuwany przez praktyków postulat: przyjęcia jednolitych zasad regulujących umowy międzynarodowej sprzedaży towarów, uwzględniających różne systemy społeczne, gospodarcze i prawne ${ }^{4}$, które przyczynią się: do usunięcia przeszkód prawnych $w$ obrocie międzynarodowym ${ }^{5}$ oraz będą sprzyjały rozwojowi handlu międzynarodowego ${ }^{6}$.

Relewantne (w odniesieniu do tematyki artykułu) zasady ponadnarodowego prawa kontraktów zostały ujęte - chronologicznie względem powstania - w skali globalnej w 1994 r. jako Reguły Międzynarodowych Umów Handlowych UNIDROIT (UNIDROIT Principles of International Commercial Contracts) ${ }^{7}$, zaś w skali europejskiej jako Zasady Europejskiego Prawa Umów (Principles of European Contract Law $)^{8}$. Warto przy tym nadmienić, że opracowywanie zarówno

1 Tak m.in. W. Popiołek, Obowiązek przyjęcia dostawy towaru w projekcie „Zasad europejskiego prawa umów” i w Konwencji ONZ o międzynarodowej sprzedaży towarów [w:] W kierunku europeizacji prawa prywatnego. Ksiega pamiątkowa dedykowana Profesorowi Jerzemu Rajskiemu, red. A. Brzozowski, W. Kocot, K. Michałowska, Warszawa 2007, s. 563.

2 W stosunku do Polski weszła w życie z dniem 1 czerwca 1996 r. (Dz.U. 1997, nr 45, poz. 286-287, s. 1538 i n.), http://prawo.sejm.gov.pl/isap.nsf/download.xsp/ WDU19970450286/O/D19970 286.pdf]; dalej: CISG, konwencja wiedeńska 1980.

3 Zob. W. Popiołek, Obowiązek przyjęcia dostawy towaru, op. cit., s. 563.

4 Zob. P. Drapała, A. Olejniczak, Dodatkowe zastrzeżenia umowne [w:] System prawa prywatnego, t. 5, Prawo zobowiązań - część ogólna, red. E. Łętowska, Warszawa 2013, s. 1539.

5 Ibidem.

6 Ibidem.

7 UNIDROIT Principles of International Commercial Contracts 2016, https://www. trans-lex.org/400120/highlight_unidroit/unidroit-principles-of-international-commerci al-contracts-2016/ [dostęp: 22 października 2019 r.]; dalej: Reguły UNIDROIT, UPICC.

8 The Principles of European Contract Law, https://www.trans-lex.org/400200/_/pecl/ [dostęp: 22 października 2019 r.], dalej: Zasady PECL, PECL. Zob. także O. Lando, 
UPICC, jak i PECL, było efektem przeprowadzonych wcześniej badań komparatystycznych, skondensowanych wokół niemal tożsamych materiałów źródłowych, tj. aktów prawnych krajowych i międzynarodowych ${ }^{9}$. Oba komentowane zbiory oparte są na podobnej aksjologii i filozofii co do funkcjonalności rozwiązań przyjętych w celu uwzględnienia potrzeb międzynarodowego obrotu handlowego, jak i w równej mierze czerpią z rozwiązań i terminologii CISG ${ }^{10}$. Z tego też względu, system wspólnych reguł wytworzony przez konwencję wiedeńską 1980 r., Reguły UNIDROIT i Zasady PECL bywa określany mianem „trojki”, stanowiącej podstawy nowoczesnego lex mercatoria ${ }^{11}$.

W dalszej kolejności należy zwrócić uwagę na najnowszą prywatnoprawną wspólnotową kodyfikację, będącą niejako sukcesorem Zasad PECL, a mianowicie Projekt Wspólnej Ramy Odniesienia (Draft Common Frame of Reference) ${ }^{12}$. W każdym wypadku wymaga jednak zaakcentowania, że normatywne fundamenty harmonizacji prawa prywatnego - kwalifikowane przez opinio communis doctorum jako lex mercatoria ${ }^{13}$ - nie mają co do zasady charakteru prawnie wiążącego (tzw. soft law) ${ }^{14}$.

Rozważania o praktycznym wpływie prawa modelowego na regulacje w systemach prawa krajowego zostaną przedstawione na przykładzie stipulated payment for non-performance, czyli prawnomodelowego odpowiednika kary umownej w prawie polskim (tj. art. 483-484 Kodeksu cywilnego ${ }^{15}$ ).

H. Beale, The Principles of European Contract Law. Part I: Performance, Non-Performance and Remedies, Dordrecht 1995. Kolejne wersje PECL zostały ogłoszone odpowiednio w roku 2000 (cz. I i II) oraz 2002 (cz. III).

9 Tak E. Rott-Pietrzyk, Interpretacja umów w prawie modelowym i wspólnym europejskim prawie sprzedaży (CESL), Warszawa 2013, s. 130.

10 Ibidem.

11 Podobnie O. Lando, CISG and Its Followers: A Proposal to Adopt Some International Principles of Contract Law, AJCL 2005, t. 53, s. 381-382; także E. Rott-Pietrzyk, Interpretacja umów, op. cit., s. 130.

12 Zob. Ch. von Bar, E. Clive, H. Schulte-Nölke, Principles, Definitions and Model Rules of European Private Law. Draft Common Frame of Reference (DCFR), Full Edition, t. I, Munich 2009, dalej: DCFR; zob. także P. Drapała, A. Olejniczak, Dodatkowe zastrzeżenia, op. cit., s. 1135 .

13 Szerzej co do pojęcia lex mercatoria zob. B. Fuchs, Lex mercatoria - pojęcie [w:] System prawa handlowego, t. 9, Międzynarodowe prawo handlowe, red. W. Popiołek, Warszawa 2013, s. 46 i n.

14 Zob. E. Rott-Pietrzyk, Interpretacja umów, op. cit., s. 105. Z kolei o charakterze przywołanych, jednolitych aktów prawnych w ramach harmonizacji międzynarodowego prawa handlowego - zob. eadem, s. 131-139.

15 Ustawa z 23 kwietnia 1964 r. - Kodeks cywilny, Dz.U. nr 16, poz. 93; t.j. Dz.U. 2019, poz. 1145; dalej: k.c. 


\section{Ogólna charakterystyka wybranych aktów prawa modelowego}

\section{UNIDROIT Principles of International Commercial Contracts (UPICC)}

Jak zostało zaznaczone, zarówno konwencja wiedeńska 1980 r., jak i UPICC mają, w odróżnieniu od PECL i DCFR, charakter aktów globalnych, stanowiących źródła regulacji w zakresie międzynarodowego obrotu handlowego. Istotne jednak, że zgodnie z pkt 8 preambuły Reguł UNIDROIT akt ten może zostać wykorzystany jako wzorzec nie tylko przez prawodawcę krajowego czy międzynarodowego, ale także jako zbiór materiałów kursowych w zakresie nauczania prawa umów na poziomie akademickim i faktyczna baza komparatystyczna ${ }^{16}$. UPICC stanowi więc zbiór reguł dla międzynarodowych umów handlowych, którego zakres zastosowania ma charakter otwarty ${ }^{17}$. Nie zdefiniowano jednak ani kryterium uznania umowy za „międzynarodową”, ani za „handlową”. Na ogół przyjmuje się - dla określania „międzynarodowości” - za czynnik decydujący siedzibę stron albo miejsce zwykłego pobytu w różnych państwach, choć oczywiście w omawianym przypadku tego wprost nie uczyniono. Nie określono też, kiedy dana czynność ma charakter "handlowy”, co presuponuje, że w braku profesjonalnego charakteru umowy można mówić o wyłączeniu możliwości zastosowania UPICC ${ }^{18}$.

Bezsporne jest również, że Reguły UNIDROIT mogą być stosowane wówczas, gdy strony uzgodnią, iż umowa podlega ogólnym zasadom prawa, lex mercatoria lub innym podobnym zasadom ${ }^{19}$. Daje to więc inter partes możliwość umówienia się, że mocą skutecznej klauzuli w łączącym je stosunku obligacyjnym wyłączają wszelkie wynikłe $z$ tego stosunku spory spod właściwości prawa określonego państwa na rzecz zastosowania wzmiankowanego już lex mercatoria czy innych zasad $^{20}$. Tym samym w braku dokonania przez strony wyboru prawa dla zawartej między nimi umowy mogą w pełni znaleźć zastosowanie Reguły UNIDROIT, przy czym to, jakiemu prawu będzie podlegała umowa, zależy, po pierwsze, od tego, czy ustalenie prawa właściwego dla danej umowy będzie zawierało się

16 Por. UNIDROIT Principles. Preamble - 8. Other possible uses of the Principles: [...] The Principles may also be used as a substitute for the domestic law otherwise applicable. This is the case whenever it proves impossible or extremely difficult to establish the relevant rule of that particular domestic law with respect to a specific issue, i.e. it would entail disproportionate efforts and/or costs. The reasons for this generally lie in the special character of the legal sources of the domestic law in question and/or the cost of accessing them. Furthermore, the Principles may be used as course material in universities and law schools, thereby promoting the teaching of contract law on a truly comparative basis.

17 Zob. E. Rott-Pietrzyk, Interpretacja umów, op. cit., s. 136-137.

18 Por. B. Fuchs, Reguty, op. cit., s. 61.

19 Ibidem, nb. 85.

20 Ibidem, nb. 86 
w gestii sądu powszechnego lub arbitrażowego ${ }^{21}$, po drugie, jaka w tej materii była wola stron ${ }^{22}$. Warto zaznaczyć, że UPICC mogą być wykorzystywane także w celu dokonywania wykładni i uzupełniania aktów międzynarodowego prawa jednolitego ${ }^{23}$ oraz prawa krajowego ${ }^{24}$, co pozwala być im prawem modelowym w tym sensie, że mogą stanowić wzorzec dla krajowego lub międzynarodowego prawodawcy.

Szczegółowo Reguły UNIDROIT zostaną jeszcze umówione w kontekście funkcjonalnego odpowiednika „kary umownej”, niemniej dużo istotniejsze znaczenie z punktu widzenia powszechnej już współcześnie koncepcji multicentryczności systemu prawa mają koncepcje przyjmowane na szczeblu wspólnotowym, omawiane w dalszej części artykułu².

\section{CECL Principles of European Contract Law}

Jak zaznaczono, Zasady PECL miały charakter prekursorski w zakresie utworzenia jednolitej europejskiej kodyfikacji obejmującej ogólne zasady unijnego

${ }^{21}$ W przypadku sądu arbitrażowego możliwość jego związania wskazaniem materialnoprawnym regulacji niemającej charakteru prawa krajowego lub międzynarodowego sensu stricto nie powinna budzić wątpliwości. Inaczej rzecz przedstawia się w kontekście związania sądu państwowego materialnoprawnym wskazaniem regulacji. Uznanie, czy sąd państwowy jest właściwy do rozpoznania sprawy z zobowiązania, dla którego strony zdecydowały się na wybór materialnoprawny, zależy od tego, czy właściwość taka przyznawana jest sądowi państwowemu przez przepisy prawa właściwego dla umowy. Podobnie zresztą o tym, czy w procesie wykładni umowy lub poszczególnych jej postanowień, dla których strony zdecydowały się sięgnąć do określonego systemu normatywnego (stosując materialnoprawne wskazanie), wolno czerpać z reguł wykładni w tym systemie, rozstrzygać będą dyrektywy wykładni umów zawarte w prawie właściwym dla umowy. Zob. w tym kontekście zwłaszcza rozważania P. Machnikowskiego i A. Brzozowskiego w zakresie mechanizmu stosowania PECL - P. Machnikowski, A. Brzozowski, Unifikacja europejskiego prawa umów. Zasady Europejskiego Prawa Umów (PECL) [w:] System prawa prywatnego, t. 5, Prawo zobowiązań - część ogólna, red. K. Osajda, Warszawa 2020, s. 496-498 i 523; M. Pazdan, Wybór prawa w świetle rozporządzenia Rzym I - analiza szczegółowa [w:] System prawa prywatnego, t. 20B, Prawo prywatne międzynarodowe, red. M. Pazdan, Warszawa 2015, s. 70 i n.; idem, Wybór kolizyjnoprawny, op. cit., s. 76.

B. Fuchs, Reguty, op. cit., nb. 86.

23 Tak M.J. Bonell, The UNIDROIT Principles Of International Commercial Contracts And CISG - Alternatives Or Complementary Instruments?, ULR 1996, t. 26, s. 33 i n.; a także B. Fuchs, Reguły, op. cit., nb. 87-88.

Zob. E. Rott-Pietrzyk, Interpretacja umów, op. cit., s. 137, oraz cytowani tam autorzy.

25 Szerzej o multicentryczności systemu zob. E. Łętowska, Multicentryczność współczesnego systemu prawa i jej konsekwencje, „Państwo i Prawo” 2005, z. 4, s. 3; a także eadem, Multicentryczność współczesnego systemu prawa i wykładnia jej przyjazna [w:] Rozprawy prawnicze: ksiega pamiątkowa Profesora Maksymiliana Pazdana, red. L. Ogiegło, W. Popiołek, M. Szpunar, Kraków 2005, s. 1127 i n. 
prawa umów, co zresztą wynika expressis verbis z art. 1:101 ust. 1 PECL ${ }^{26}$. Ich stosowanie dotyczy przede wszystkim wspólnotowych stosunków zobowiązaniowych, a więc wyłącznie tych podmiotów, o których można powiedzieć, że mają przynależność wspólnotową ${ }^{27}$. W przypadku osób fizycznych kryterium bez wątpliwości będzie łącznik miejsca ich zwykłego pobytu ${ }^{28}$. Większe trudności pojawiają się w przypadku przedsiębiorstw, wobec których w celu uzyskania statusu przedsiębiorstwa wspólnotowego wymaga się kumulatywnego spełnienia dwóch kryteriów: 1) założenia zgodnie z prawem któregokolwiek państwa UE oraz 2) posiadania statutowej siedziby, zarządu lub głównego przedsiębiorstwa w obrębie Unii ${ }^{29}$.

Nie budzi wątpliwości, że Zasady PECL będą najczęściej stosowane między uczestnikami obrotu profesjonalnego mającymi siedzibę na terytorium UE. Jednakże nie można wykluczać także ich międzynarodowego oddziaływania w sytuacji, kiedy tylko jedna ze stron umowy będzie miała przynależność wspólnotową, druga zaś wywodzić się będzie spoza granic Unii ${ }^{30}$. Podobnie zresztą nie można ograniczać ich zastosowania wyłącznie do umów zawieranych między uczestnikami obrotu profesjonalnego, delimitując zastosowanie w odniesieniu do umów o charakterze konsumenckim ${ }^{31}$.

Mimo zaklasyfikowania Zasad PECL jako soft law, nie można odmówić im mocy wiążącej w dwóch przypadkach: kiedy strony w ramach danego stosunku obligacyjnego zastrzegą, że poddają łączącą je umowę Zasadom PECL ${ }^{32}$, jak i w sytuacji, kiedy strony wyraziły zgodę na poddanie ich umowy general principles of law, lex mercatoria bądź innym podobnym zasadom ${ }^{33}$. W pierwszym wypadku chodzi więc o klauzulę materialnoprawnego wskazania regulacji, która w obrocie międzynarodowym ma charakter powszechnie stosowany (tzw. wariant podstawowy $)^{34}$. W drugim wypadku, rozważając pojęcie general principles

${ }^{26}$ Zgodnie $\mathrm{z}$ tym przepisem: These Principles are intended to be applied as general rules of contract law in the European Communities.

27 Tak E. Wieczorek, Zasady europejskiego prawa umów, Gdańsk 2005, s. 11.

28 Szerzej na ten temat zob. M. Pazdan, E. Rott-Pietrzyk, Łaczniki w normach kolizyjnych [w:] System prawa prywatnego, t. 20B, Prawo prywatne międzynarodowe, red. M. Pazdan, Warszawa 2015, s. 231 i n.

29 Tak E. Wieczorek, Zasady, op. cit., s. 11.

30 Ibidem, s. 12.

31 Ibidem.

32 Zob. art. 1:101 ust. 2 Zasad PECL.

33 Zob. art. 1:101 ust. 3 Zasad PECL.

34 Korzystając z przysługującej autonomii woli stron - również na gruncie kolizyjnym strony nie określają tutaj wzajemnych praw i obowiązków, ale dokonują wskazania oznaczonego porządku prawnego (niekoniecznie krajowego), według reguł którego ma być oceniane powstanie, treść i wykonanie danego zobowiązania; szerzej o problematyce wyboru prawa i kwestii ustalania prawa właściwego w braku wyboru prawa zob. M. Paz- 
of law (tzw. wariant alternatywny), należy mieć na względzie zwłaszcza orzecznictwo TSUE ${ }^{35}$, które bardzo często odwołuje się do tradycji prawnych poszczególnych państw członkowskich ${ }^{36}$. Przywołane tutaj wyliczenie ma charakter przykładowy ${ }^{37}$. Co istotne, poziom ogólności wymienionych zbiorów norm sprawia, że nie nadają się one do bezpośredniego stosowania i wymagają każdorazowej konkretyzacji $a c a s u^{38}$, zaś same strony mogą także wyłączyć zastosowanie którejkolwiek z norm PECL (w tym uchylić lub zmienić wynikające z tego aktu skutki), chyba że z określonej zasady wynika co innego ${ }^{39}$.

Zasady PECL mogą znaleźć zastosowanie również w tych stanach faktycznych, dla których wskazany system prawny lub przepisy prawa właściwego nie przewidują żadnego rozstrzygnięcia ${ }^{40}$. Nie stoi tutaj na przeszkodzie okoliczność, że umowa podlega określonemu porządkowi prawnemu bądź to na skutek wybranego dla niej prawa, bądź na skutek zastosowania określonych łączników ${ }^{41}$. Można wręcz syntetycznie przyjąć, że PECL znajdzie zastosowanie w razie konieczności wypełnienia luk występujących zarówno w regulacjach pochodzących od ustawodawcy krajowego, jak i w aktach legislacji międzynarodowej, w szczególności w międzynarodowych konwencjach branych pod uwagę na etapie ustalania prawa właściwego, np. konwencji wiedeńskiej $1980 \mathrm{r}^{42}$. We wskazanych tu okolicznościach o zastosowaniu Zasad PECL każdorazowo rozstrzygać będzie organ stosujący ${ }^{43}$.

Uwaga „techniczna” dotyczy tego, że Zasady PECL stanowią, co prawda, bazę dla harmonizacji prawa prywatnego w ramach Unii Europejskiej ${ }^{44}$, jednak sam

dan, Wybór prawa, op. cit., s. 70 i n.; szczegółowo kwestie te rozważają także B. Fuchs, M. Jagielska i in., Prawo właściwe w braku wyboru prawa [w:] System prawa prywatnego, t. 20B, Prawo prywatne międzynarodowe, red. M. Pazdan, Warszawa 2015, s. 95-353.

Zob. B. Fuchs, Reguty, op. cit., s. 61.

36 Pozwala to tym samym na wyodrębnienie pewnego niekwestionowanego w doktrynie katalogu zasad o fundamentalnym znaczeniu dla praktyki obrotu, do którego zalicza się m.in. zasady pacta sunt servanda, bona fides, clausula rebus sic stantibus, ochrony praw nabytych czy ochrony zaufania; szerzej zob. E. Wieczorek, Zasady, op. cit., s. 14.

37 Tak też E. Rott-Pietrzyk, Harmonizacja prawa prywatnego w aktach prawa modelowego (soft law) [w:] System prawa handlowego, t. 9, Międzynarodowe prawo handlowe, red. W. Popiołek, Warszawa 2013 s. 54.

38 Podobnie A. Szumański, Renegocjacje umów w międzynarodowym obrocie gospodarczym. Studium prawnoporównawcze, Kraków 1994, s. 75.

39 Zob. art. 1:102 ust. 2 PECL, który stanowi, że [...] the parties may exclude the application of any of the Principles or derogate from or vary their effects, except as otherwise provided by these Principles. Zob. art. 1:101 ust. 4 Zasad PECL.

${ }^{41}$ Zob. E. Wieczorek, Zasady, op. cit., s. 14.

42 Tak E. Rott-Pietrzyk, Interpretacja umów, op. cit., s. 132.

43 Ibidem, s. 132, a także cytowani tam autorzy.

44 Jest to jednak jeden z tzw. celów długoterminowych; tak też E. Rott-Pietrzyk, Harmonizacja umów, op. cit., s. 57. Autorka ta wskazuje również, że: [cel długoterminowy - 
proces harmonizacyjny należy odróżniać od ujednolicenia prawa w drodze formalnego instrumentu normatywnego ${ }^{45}$, za który uchodzi chociażby projektowane rozporządzenie $\mathrm{CESL}^{46}$. Ma to istotne znaczenie na etapie dokonywania oceny „siły związania” prawodawców krajowych normami ponadnarodowymi przyjętymi w ramach harmonizacji prawa prywatnego (odrębną sprawą jest kwestia podnoszenia jakości tzw. acquis communautaire ${ }^{47}$ ). Można wręcz przyjąć, że często ujednolicanie instrumentem normatywnym stanowi konkretyzację postulatu ogólnej harmonizacjii ${ }^{48}$, co pozostaje nie bez znaczenia dla dalszych rozważań, których przedmiot jest obecnie w fazie założeń ogólnych.

\section{Wspólny System Odniesienia (DCFR)}

Draft Common Frame of Reference (DCFR) ${ }^{49}$ ma stanowić, według zamysłu twórców, fundament $\mathrm{w}$ procesie opracowywania wspólnych "politycznych instrumentów" w ramach acquis communautaire. Został pomyślany jako następca Zasad PECL, będący kolejnym krokiem na drodze unifikacji europejskiego prawa umów i w rozwoju wspólnotowego prawa modelowego ${ }^{50}$.

Po dokonaniu porównania obu aktów nie trudno zauważyć, że Zasady PECL zostały całkowicie inkorporowane przez DCFR, stanowiący ich poszerzoną wersję. Zabieg ten objął księgi I, II oraz III, które zdają się tożsame w obu aktach. Poszerzenie objęło natomiast całkowicie oderwane od konstrukcji Zasad PECL księgi IV-X, które wykraczają poza zakres części ogólnej prawa umów oraz części ogólnej dotyczącej wykonania i niewykonania zobowiązań umownych ${ }^{51}$. Swoim zakresem odnoszą się do pozaumownych źródeł zobowiązań, w szczególności bezpodstawnego wzbogacenia, negotiorum gestio oraz deliktów, a także problematyki powiernictwa, przeniesienia własności nieruchomości czy zabezpiecze-

przyp. A.M.J.] jest również realizowany i znajduje obecnie odzwierciedlenie $w$ instrumencie opcjonalnym.

45 Ibidem.

46 Proposal for a Regulation of the European Parliament and the Council on a Common European Sales Law, https://eur-lex.europa.eu/legal-content/EN/ TXT/?uri=CELEX\%3A52011PC0635 [dostęp 6 kwietnia 2019 r.]; dalej: CESL.

47 Szerzej na temat pojęcia acquis communautaire zob. np. A. Dana, Miejsce „acquis communautaire” w Konstytucji Rzeczypospolitej Polskiej, „Doctrina. Studia Społeczno-polityczne" 2006-2007, nr 3-4, s. 205-219.

48 Tak zdaje się E. Rott-Pietrzyk, Harmonizacja prawa prywatnego, op. cit., s. 57.

49 Draft Common Frame of Reference (DCFR) jest tłumaczony albo jako Wspólny System Odniesienia, albo jako Wspólne Ramy Odniesienia. W niniejszej pracy oba zwroty będą stosowane zamiennie. Szerzej co do terminologii zob. E. Rott-Pietrzyk, Harmonizacja prawa prywatnego, op. cit., s. 69

50 Tak E. Rott-Pietrzyk, ibidem.

51 Por. Ch. von Bar, E. Clive, H. Schulte-Nölke, Principles, Definitions and Model Rules, op. cit., s. 131 i n. 
nia na rzeczach ruchomych ${ }^{52}$. Najbardziej uwagę przykuwa fakt, że twórcy DCFR odstąpili od konstruowania jego założeń na podstawie umowy jako naczelnej instytucji Systemu, posługując się szerszym pojęciem „zobowiązania”" ${ }^{3}$. Co więcej, obok pojęcia „zobowiązania” istotna rola w DCFR jest przypisywana także „Czynności prawnej” (art. II-1:101) ${ }^{54}$.

Co ciekawe, jedna z najczęściej przywoływanych wokół DCFR kontrowersji ma charakter formalno-merytoryczny w tym sensie, że odwołuje się do normatywnych podstaw struktury i funkcjonowania DCFR w prawie unijnym, a także wskazuje na brak w jego założeniach mocnej podstawy komparatystycznej ${ }^{55}$. Przytacza się wręcz, że System opiera się głównie na XIX-wiecznym modelu kontynentalnego prawa cywilnego (ze szczególnie silnymi rysami prawa germańskiego i romańskiego), wypaczając założenia modeli skandynawskiego i common law. Prowadzić to może w efekcie do wyraźnej bipolaryzacji między różniącymi się instytucjami przywołanych modeli, tym samym uniemożliwiając sprawowanie roli faktycznego „układu odniesienia”. W odpowiedzi na te zarzuty autorzy DCFR podają, że wybrana przezeń normatywna struktura daje maksymalną elastyczność, którą można zapewnić przy nie do końca sprecyzowanych dziś celach, którym jednolite DCFR ma sprostać w przyszłości. Zdaniem twórców łatwiej jest bowiem w razie konieczności wprowadzać zmiany do części ogólnej prawa zobowiązań (jak np. w związku z ewentualnym pojawieniem się rozporządzenia CESL), niż rozbudowując prawo umów tak, by jego reguły mogły objąć zobowiązania pozaumowne ${ }^{56}$. Ponadto, jak słusznie zauważono, regulacja części ogólnej prawa zobowiązań, a w szczególności relewantnych z punktu widzenia dalszej części artykułu skutków niewykonania zobowiązania w akcie takim jak DCFR, jest wysoce pożądana przez wzgląd na konieczność zapewnienia sankcji zawartym w tym akcie obowiązkom przedkontraktowym i antydyskryminacyjnym, których w prekursorskich Zasadach PECL próżno było szukaćs7.

Najpoważniejsze z zarzutów kierowanych przeciwko Systemowi dotyczą jednak jego prawnego charakteru, a ściślej rzecz ujmując - podstaw legitymacji twórców DCFR do kształtowania europejskiego prawa prywatnego, której

52 Zob. E. Rott-Pietrzyk, Harmonizacja prawa prywatnego, op. cit., s. 70

53 Zob. P. Machnikowski, T. Pajor, Prawo prywatne Unii Europejskiej i jego wplyw na prawo polskie [w:] System prawa prywatnego, t. 1, Prawo cywilne - część ogólna, red. M. Safjan, Warszawa 2012, s. 311.

54 Podobnie P. Machnikowski, T. Pajor, Prawo prywatne, op. cit., s. 312, oraz cytowani tam autorzy.

55 Ibidem.

56 Zob. Ch. von Bar, E. Clive, H. Schulte-Nölke, Principles, Definitions and Model Rules, op. cit., s. 38-41.

57 Zob. P. Machnikowski, T. Pajor, Prawo prywatne Unii Europejskiej, op. cit., s. 312 in fine. 
wprost zarzuca się brak demokratycznej proweniencji ${ }^{58}$. Przy czym i ten zbiór argumentów bywa kontrowany przez podniesienie braku należytej dyferencjacji między akademicką i polityczną stroną Systemu. Jednak z uwagi na wyłącznie naukowy „rodowód” DCFR nie można żądać od jego twórców wykazania demokratycznej legitymacji wynikającej z prawa wspólnotowego, zaś ewentualne działania wymagające tejże legitymacji będą podejmowane tylko przez uprawnione do tego organy Unii Europejskiej ${ }^{59}$.

$\mathrm{Z}$ punktu widzenia prawa polskiego stosowanie reguł wynikających z prawa modelowego jako reguł normatywnych możliwe będzie wyłącznie w przypadku, gdy podmiot rozstrzygający spór będzie miał możność niekierowania się wiążącym wskazaniem prawa właściwego przez reguły kolizyjne prawa polskiego. Nietrudno więc dostrzec tutaj „komfortową” w pewnym sensie pozycję sądów arbitrażowych. Z kolei w odniesieniu do sytuacji, gdzie przepisy prawa modelowego przewidują swoje zastosowanie w sytuacji włączenia ich do umowy czy też wprowadzenia przez strony klauzuli poddającej umowę ich kognicji, w doktrynie dostrzeżono ${ }^{60}$, że nie będzie to mimo wszystko wspomniany uprzednio kolizyjnoprawny wybór prawa, a raczej materialnoprawne wskazanie regulacji ${ }^{61}$. To pierwsze zawsze oznacza bowiem poddanie zobowiązania określonemu systemowi prawnemu (tj. prawu merytorycznemu określonego państwa ${ }^{62}$, którego prawo jako wybrane staje się prawem właściwym dla określonego stosunku obligacyjnego. Trudno zatem reguły vel zasady prawa modelowego utożsamiać z prawem merytorycznym państwa, zważywszy, że te pierwsze mają, jak już wielokrotnie wspomniano, charakter soft law.

Konstrukcja materialnoprawnego wskazania regulacji prawnej stanowi natomiast jeden z najbardziej światłych przejawów swobody kontraktowej stron, której granice określa prawo merytoryczne właściwe dla stosunku zobowiązaniowego. Co istotne, przy konstruowaniu skutecznej inter partes umowy strony mogą albo włączyć do umowy postanowienia, mechanizmy czy instytucje zaczerpnięte z wybranego systemu prawa czy zbioru norm (inkorporacja), albo też wprost odwołać się do konkretnej regulacji (interpolacja) ${ }^{63}$. Posłużenie się materialnoprawnym wskazaniem dopuszczalne jest jednak wyłącznie w granicach norm

$58 \quad$ Ibidem, s. 313.

59 Ibidem.

60 Ibidem, s. 314; także J. Skąpski, Autonomia woli w prawie prywatnym międzynarodowym w zakresie zobowiązań z umów, Kraków 1964, s. 31; J. Gołaczyński, Prawo prywatne międzynarodowe, Warszawa 2003, s. 126 i n.

${ }_{61}$ Szerzej na temat materialnoprawnego wskazania regulacji prawnej zob. M. Pazdan, Wybór kolizyjnoprawny, op. cit., s. 74-75. Co do związania sądu państwowego materialnoprawnym wskazaniem zob. przyp. 21.

62 Ibidem, s. 75.

63 Ibidem. 
ustanawiających swobodę kontraktową w rodzimym systemie prawa ${ }^{64}$. Prowadzi to do wniosku, że powołane w taki sposób normy nie będą mogły zastąpić norm imperatywnych lub semiimperatywnych prawa krajowego, w przeciwieństwie do norm o charakterze dyspozytywnym ${ }^{65}$.

\section{Kara umowna jako agreed payment for non-performance w UNIDROIT PICC}

Jak wspomniano, praktyczne działanie prawa modelowego zostanie przedstawione na przykładzie regulacji kary umownej zarówno w tym prawie, jak i w porównaniu z rozwiązaniami przyjętymi przez ustawodawcę polskiego. Z uwagi na szeroki zakres zastosowania Reguł UNIDROIT w skali globalnej ${ }^{66}$ zostaną one rozważone w pierwszej kolejności.

Już na wstępie warto sprostować, że Reguły UPICC nie określają interesującego nas dodatkowego zastrzeżenia umownego „karą umowną"67. Podobnie zresztą żaden akt europejskiego prawa modelowego nie posługuje się tym pojęciem wprost, wprowadzając właściwe sobie odpowiedniki ${ }^{68}$. I tak Reguły w art. 7.4.13 pkt 1 posługują się pojęciem agreed payment for non-performance, czyli „uzgodnionej płatności za niewykonanie" ${ }^{\text {" }}$. Zgodnie z treścią tego przepisu: jeżeli umowa przewiduje, że strona, która nie spełni swojego świadczenia, zapłaci $z$ tego tytułu określona sumę pieniężną, suma ta należy się wierzycielowi niezależnie od faktycznie poniesionej szkody [wyróżnienie - A.M.J.] ${ }^{70}$.

Odnosząc się do wykładni literalnej komentowanego przepisu, trzeba wziąć pod uwagę kilka okoliczności. Po pierwsze, nie budzi zastrzeżeń, że regulacja art. 7.4.13 pkt 1 UPICC ma charakter w wysokim stopniu syntetyczny. Jest to $\mathrm{z}$ pewnością pożądane $\mathrm{z}$ uwagi na dzisiejszy zintensyfikowany rozwój między-

64 Tak też J. Skąpski, Autonomia woli, op. cit., s. 31.

65 Podobnie o niemożności pozostawania w sprzeczności norm prawa obcego, powołanych w skutek materialnoprawnego wskazania regulacji względem przepisów kogentnych prawa krajowego - zob. M. Pazdan, Wybór kolizyjnoprawny, op. cit., s. 76 in fine; zob. także Prawo prywatne Unii Europejskiej, op. cit., s. 315.

${ }_{66}$ Tak M. Romanowski, Ogólne reguły wykładni kontraktów w świetle zasad europejskiego prawa kontraktów a reguly wykładni umów w prawie polskim, „Przegląd Prawa Handlowego" 2004, nr 8, s. 11.

67 Zob. Reguły UNIDROIT, art. 7.4.13, s. 339.

68 Por. art. 7.4.13 pkt. 1 UPICC, art. 9: 305 ust. 1 PECL, art. III-3:712 ust. 1 DCFR.

69 Zob. M. Jagielska, M. Szpunar, Polski przekład Reguł UNIDROIT, „Problemy Prawa Handlu Zagranicznego" 2000, t. 19/20, s. 358.

70 Ibidem; dla przejrzystości rozważań, aby uniknąć każdorazowego powtarzania formuły o „uzgodnionej płatności za niewykonanie”, posługiwał się będę zamiennie terminem agreed payment, kary umownej lub kary umownej w UPICC. 
narodowych stosunków handlowych i dywersyfikację podmiotów w nich uczestniczących. Taki zresztą był zamysł samych autorów przedmiotowej regulacji, tj. konstrukcja definicji na tyle modalnej, aby strony w zakresie łączącej je umowy mogły swobodnie konstruować klauzule o charakterze kompensacyjnym, symplifikacyjnym czy represyjno-prewencyjnym, w zależności od preferowanego przez nie celu, którego osiągnięcie to zastrzeżenie miałoby wspierać ${ }^{71}$. Konsekwencją tych założeń jest posługiwanie się przez UPICC pojęciem „ustalonej płatności”, które obejmować będzie zarówno świadczenia zastrzeżone tytułem odszkodowania, jak i te, które mają zapewnić realne wykonanie zobowiązania przez przymuszenie dłużnika do zaspokojenia wierzyciela zgodnie $\mathrm{z}$ treścią stosunku podstawowego.

Po drugie, Reguły odwołują się do istnienia oznaczonej „umowy”, z której wynikał będzie obowiązek dłużnika do zapłaty określonej sumy wierzycielowi na skutek niespełnienia swojego świadczenia. Ma to istotne znaczenie w odniesieniu zarówno do polskiej konstrukcji kary umownej, jak i w prospekcie rozważań o karze umownej w europejskim prawie modelowym. W pierwszym przypadku ustawodawca polski w treści art. $483 \$ 1$ in principio k.c. powiada, że: można zastrzec w umowie [wyróżnienie - A.M.J.], że naprawienie szkody [...]. Wskazuje to na zbieżność zarówno twórców Reguł UNIDROIT, jak i ustawodawcy polskiego co do „fundamentu”, na którym co do zasady możliwe jest konstruowanie kary umownej. W obu regulacjach expressis verbis przyjęto kontrakt. Z kolei drugi przypadek zostanie, co prawda, szczegółowo omówiony w punkcie poświęconym Zasadom PECL i prawu DCFR, to jednak warto już teraz zasygnalizować, że podstawy zastrzeżenia kary umownej w tych aktach są odmienne.

Po trzecie, przedmiot kary umownej w Regułach UNIDROIT został zawężony do specified sum ${ }^{72}$, czyli oznaczonej sumy należnej wierzycielowi. Zgodnie bowiem $\mathrm{z}$ art. $7.4 .13 \mathrm{pkt}$ 1: where the contract provides that a party who does not perform is to pay specified sum [wyróżnienie - A.M.J.] to the aggrieved party $[\ldots]^{73}$. W tym zakresie definicja ta pozostaje zbieżna $\mathrm{z}$ regulacją art. $483 \$ 1$ in fine k.c., w której ustawodawca rozstrzygnął, że naprawienie szkody wynikłej z niewykonania lub nienależytego wykonania zobowiązania niepieniężnego nastąpi przez „zapłatę określonej sumy”. Warto przy tym przypomnieć, że definicja agreed payment obejmuje klauzule ustalające ex ante zryczałtowane odszkodowanie $\mathrm{z}$ tytułu niewykonania zobowiązania zarówno w celu represyjnym, jak i kompensacyjnym ${ }^{74}$.

71 Zob. Reguły UNIDROIT, s. 284.

72 Tak też P. Drapała, A. Olejniczak, Dodatkowe zastrzeżenia, op. cit., s. 1136.

73 Zob. Reguły UNIDROIT, s. 289.

74 Tak P. Drapała, A. Olejniczak, Dodatkowe zastrzeżenia, op. cit., s. 1135. Zob. także A.M. Juranek, Kara umowna, wybrane klauzule quasipenalne oraz klauzule indemnifikacyjne $w$ prawie polskim i prawie modelowym. Rozważania de lege lata $i$ de lege ferenda, Katowice 2019, s. 15-17. 
Po czwarte, twórcy Reguł UNIDROIT zastrzegli, że roszczenie wierzyciela o zapłatę kary umownej powstaje bez względu na okoliczność poniesienia przez niego szkody (irrespective of its actual harm ${ }^{75}$ ), a więc tym bardziej irrelewantna jest jej wysokość. Ma to przemożne znaczenie wobec toczącej się w polskiej doktrynie dyskusji w kontekście związku między roszczeniem o zapłatę kary umownej a szkodą, której niewystąpienie w dalszym ciągu uznawane jest przez część piśmiennictwa za negatywną przesłankę dochodzenia komentowanego roszczenia $^{76}$. Co istotne, również analiza najnowszego orzecznictwa wskazuje na coraz częstsze odwoływanie się sądów krajowych do regulacji prawa modelowego, co de lege ferenda implikuje konieczność wzięcia pod uwagę przyjmowanych przez nie rozwiązań 77 .

\section{Zob. art. 7.4.13 pkt 1 in fine UPICC.}

76 Za możnością zwolnienia się przez dłużnika z obowiązku zapłaty kary umownej w razie wykazania, że wierzyciel w ogóle szkody nie poniósł, opowiedzieli się m.in. J. Dąbrowa, Kara umowna [w:] System prawa cywilnego, t. III, cz. 1, Prawo zobowiazań - część ogólna, red. Z. Radwański, Warszawa 1981, s. 831; K. Zagrobelny, Komentarz do art. 484 [w:] Kodeks cywilny. Komentarz, red. E. Gniewek, P. Machnikowski, Warszawa 2017, s. 1021; P. Drapała, A. Olejniczak, Dodatkowe zastrzeżenia, op. cit., s. 1149-1150; wcześniej także W. Warkałło, Wykonywanie zobowiązań i skutki ich niewykonania według Kodeksu cywilnego, „Państwo i Prawo” 1965, z. 8-9, s. 216. Odmiennie, a więc w obronie interesu wierzyciela m.in. Z. Radwański, A. Olejniczak, Zobowiązania - część ogólna, Warszawa 2014, s. 365-367; W. Borysiak, Glosa do uchw. SN (7) z 06.11.2003 r., sygn. akt III CZP 61/03, „Monitor Prawniczy” 2007, nr 6; F. Zoll, Pojęcie niewykonania i nienależytego wykonania zobowiązania oraz kwalifikowane postaci naruszenia zobowiazania i ich skutki [w:] System prawa prywatnego, t. 6, Prawo zobowiązań - czesść ogólna, red. A. Olejniczak, Warszawa 2018, s. 1219-1220; W. Popiołek, Komentarz do art. 483 [w:] Kodeks cywilny, t. II, Komentarz. Art. 450-1088, red. K. Pietrzykowski, Warszawa 2018, nb. 4; wcześniej także J. Szwaja, Kara umowna wedtug Kodeksu cywilnego, Warszawa 1967, s. 89.

77 Zob. uchwała SN (7) z 6 listopada 2003 r., sygn. akt III CZP 61/03, OSNC 2004, nr 5, poz. 69, w której stwierdzono, że: za wyrażonym $w$ uchwale stanowiskiem mogq przemawiać także rozwiązania prawne przyjmowane $w$ ramach regulacji prawa kontraktowego o charakterze międzynarodowym, dotyczące bezpośrednio instytucji kary umownej. W art. 7.4.13 przyjętych przez UNIDROIT zasad międzynarodowych umów handlowych z 5.1994 r. (Principles of International Commercial Contracts), stwierdzono, że jeżeli w umowie określono, iż strona, która jej nie wykona, zapłaci drugiej stronie określona kwotę $w$ razie niewykonania zobowiązania, to druga strona będzie uprawniona do żądania tej kwoty niezależnie od faktycznie poniesionej szkody. Jeżeli nie postanowiono inaczej, wspomniana kwota pieniężna może być obniżona do odpowiedniej wysokości, gdy jest rażąco wygórowana w relacji do szkody wynikajacej z niewykonania zobowiązania lub innych okoliczności. Podobna regulację zawarto $w$ art. $9.5 .09 \mathrm{za}$ sad europejskiego prawa kontraktowego (The Principles of European Contract Law $z 7.1998$ r., Europdische Vertagsrechts-vereinheitlichung unddeutsches Recht, Tubingen, 2000, s. 219 i nast.); a także wyrok SN z 24 czerwca 2014 r., sygn. akt I CSK 392/13, 
Piąte zastrzeżenie - zdaje się najistotniejsze z punktu widzenia konstrukcji kary wadialnej przyjętej w Kodeksie cywilnym - odnosi się do charakteru zobowiązania, którego niewykonanie lub wykonanie w sposób nienależyty wiąże się z powstaniem po stronie wierzyciela roszczenia o zapłatę kary umownej. W polskiej doktrynie przeważa stanowisko, że kara ta może zostać zastrzeżona wyłącznie względem świadczenia o charakterze niepieniężnym ${ }^{78}$. Niektórzy autorzy akcentują jednak, że nie jest niedopuszczalne zastrzeżenie w umowie obowiązku zapłaty oznaczonej sumy pieniężnej w związku z niewykonaniem lub nienależytym wykonaniem zobowiązania, jednak nie będzie to kara umowna w rozumieniu art. $483 \$ 1$ k.c. $^{79}$. Konsekwencją przyjęcia tego poglądu jest delimitacja możności zastrzegania kar umownych wyłącznie do zobowiązań o charakterze niepieniężnym, która nie występuje ani w Regułach UNIDROIT, ani w innych omawianych przeze mnie aktach prawa modelowego. Autorzy UPICC stoją na stanowisku, że dynamika współczesnego obrotu gospodarczego wymusza na prawodawstwie przyjmowanie takich założeń, które przyczynią się do uelastycznienia regulacji krajowych w zakresie, w jakim poprawi to płynność i rozwój stosunków w handlu, szczególnie międzynarodowym ${ }^{80}$. Wprowadzanie niemodalnych regulacji, ograniczających swobodę kontraktową stron w zakresie pożądanych przezeń zastrzeżeń przymuszających do realnego wykonania zobowiązania nie jest poglądem, który w ówczesnych realiach może zasługiwać na poparcie. Należałoby w zasadzie dopuścić każdą możliwość umówienia się stron co do tego, w jaki sposób chcą zabezpieczyć wykonanie istniejącego między nimi zobowiązania (o charakterze pieniężnym lub niepieniężnym), o ile tylko nie będzie to stanowiło naruszenia zasad rządzących swobodą kontraktowania, porządku publicznego państwa, którego prawu umowa jest poddana, czy w końcu jakichś innych reguł, honorowanych w handlu międzynarodowym (w postaci zarówno ogólnych zasad prawa, jak i lex mercatoria oraz innych) ${ }^{81}$.

Szósta uwaga dotyczy kwestii, która w Kodeksie cywilnym została expressis verbis rozstrzygnięta przez ustawodawcę, natomiast w Regułach UNIDROIT ma charakter niejednoznaczny. Próżno bowiem szukać w art. 7.4.13 pkt 1 i 2 UPICC odniesienia się do kwestii odpowiedzialności dłużnika, a konkretniej - zakresu tejże. W prawie polskim stosuje się w tym kontekście m.in. art. 473 k.c., mocą którego dłużnik może w drodze umowy przyjąć na siebie odpowiedzialność za

Legalis; uchwała SN z 19 listopada 2010 r., sygn. akt III CZP 70/10; wyrok SN z 5 października 2006 r., sygn. akt IV CSK 157/06; szczególnie także wyrok SA w Katowicach z 24 września 2014 r., sygn. akt I ACa 378/14, Legalis.

78 Szerzej nt. zob. A.M. Juranek, Kara umowna, op. cit., s. 15 i n.

79 Zob. F. Zoll, Pojęcie niewykonania, op. cit., s. 1225.

80 Zob. Reguły UNIDROIT, s. 289.

81 Można przyjąć, że w podobnym kierunku zmierza P. Widerski, Charakter prawny kary umownej wedtug prawa polskiego na tle ponadnarodowych uregulowań prawnych, „Studia Prawa Prywatnego” 2018, nr 2, s. 12-13. 
niewykonanie lub nienależyte wykonanie zobowiązania z powodu wskazanych w tej umowie okoliczności, za które na mocy przepisów ustawy odpowiedzialności by nie ponosił. W przypadku Reguł UNIDROIT, co prawda, nie wynika to $\mathrm{z}$ treści art. 7.4.13 pkt 1 i 2, natomiast w komentarzu do tego przepisu zaznaczono, że za niewykonanie zobowiązania dłużnik musi ponosić odpowiedzialność ${ }^{82}$. Nie stoi to jednak na przeszkodzie odmiennego umówienia się inter partes, a więc wprowadzenia do umowy klauzuli, która zakres odpowiedzialności dłużnika rozszerzy również na niewykonanie lub nienależyte wykonanie tych obowiązków umownych, za których niewykonanie lub nienależyte wykonanie „W wersji podstawowej” odpowiedzialności by nie poniósł³. Przyjęcie rozszerzonej odpowiedzialności przez dłużnika na podstawie prawa polskiego ma jednak ten skutek, że takie zastrzeżenie jest traktowane jako tzw. zobowiązanie typu gwarancyjnego $^{84}$, nie zaś jako kara umowna ${ }^{85}$. Może mieć charakter co najwyżej zbliżony do kary umownej ${ }^{86}$. Oczywiście - powołany art. 473 k.c. nie jest jedyną możliwością w zakresie modyfikacji zakresu ustawowej odpowiedzialności dłużnika; odpowiednie zastosowanie znajdzie chociażby art. $353^{1}$ k.c. ${ }^{87}$.

\section{Zob. Reguły UNIDROIT, s. 289.}

83 Ibidem; podobnie P. Widerski, Charakter prawny kary, op. cit., s. 13.

84 Kwestia ta jest wielorako rozumiana terminologicznie; także w postaci „klauzuli gwarancyjnej”, „kary gwarancyjnej”, „zobowiązania gwarancyjnego” itp.

85 Reperkusją przyjęcia takiego stanowiska może być to, że względem zobowiązań typu gwarancyjnego co do zasady nie stosuje się instrumentu miarkowania, który w kontekście kary umownej przewiduje art. 484 k.c. - szerzej nt. zob. A.M. Juranek, Kara umowna, op. cit., s. 93-96; także literaturę cytowaną w przypisie 88. Z kolei o różnicach między karą umowną i zobowiązaniem gwarancyjnym zob. także Z. Radwański, A. Olejniczak, Zobowiązania, op. cit., s. 335; J. Dąbrowa, Kara umowna, op. cit., s. 829; K. Zagrobelny, Komentarz do art. 483 [w:] Kodeks cywilny. Komentarz, red. E. Gniewek, P. Machnikowski, Warszawa 201 s. 902; E. Skowrońska-Bocian, Kara umowna kompensacja czy represja?, „Zeszyty Prawnicze UKSW” 2003, nr 3/2, s. 192. Niektórzy autorzy przyjmują, że nie można ustanowić kary umownej jako zobowiązania o charakterze wyłącznie gwarancyjnym w tym znaczeniu, że dłużnik byłby zobligowany do świadczenia kary, mimo że nie ponosi odpowiedzialności z tytułu niewykonania (nienależytego wykonania) zobowiązania - tak P. Drapała, A. Olejniczak, Dodatkowe zastrzeżenia, op. cit., s. 1152.

86 Tak SN w wyroku z 15 października 2008 r., sygn. akt I CSK 154/08, Legalis.

87 Szerzej zob. także K. Zagrobelny, Komentarz do art. 472 [w:] Kodeks cywilny. Komentarz, red. E. Gniewek, P. Machnikowski, Warszawa 2017, s. 904; W. Popiołek, Komentarz do art. 472 [w:] Kodeks cywilny, t. II, Komentarz. Art. 450-1088, red. K. Pietrzykowski, Warszawa 2018, nb. 2; M. Lemkowski, Kara umowna w przypadku odstapienia od umowy [w:] Kodeks cywilny, t. II, Komentarz do art. 353-626, red. M. Gutowski, Warszawa 2019, nb. 10, oraz cytowani tam autorzy; F. Zoll, Pojęcie niewykonania, op. cit., s. 1172. 
Ostatnia uwaga dotyczy relewantności wyboru dokonanego między stronami stosunku obligacyjnego co do tego, za pomocą jakiego „kształtu” klauzuli zabezpieczą wykonanie zobowiązania. Chodzi tutaj oczywiście o to, czy będzie to klasyczna kara umowna, o której mowa w art. 483 k.c. i art. 7.4.13 pkt 1 UPICC, z jednocześnie skorelowanym odpowiednio $\mathrm{w}$ art. $484 \$ 2$ k.c. i art. 7.4 .13 pkt 2 UPICC instrumentem miarkowania, czy zobowiązanie typu gwarancyjnego, względem którego stosowanie tego mechanizmu pozostaje kwestią dyskusyjną ${ }^{88}$. Należy zważyć, że zarówno Reguły UNIDROIT ${ }^{89}$, jak i część przedstawicieli polskiej doktryny ${ }^{90}$ istnienie szkody słusznie uznaje za jedną z przesłanek, które winny zostać uwzględnione na etapie ewentualnego miarkowania kary wadialnej, nie zaś jako przesłankę negatywną co do powstania samego roszczenia o jej zapłatę.

\section{Kara umowna jako agreed payment for non-performance w Zasadach PECL i stipulated payment for non-performance w Systemie DCFR}

Mając na uwadze dokonane już omówienie zależności pomiędzy Zasadami PECL a prawem modelowym DCFR, ograniczę się wyłącznie do stwierdzenia, że w zakresie kary umownej oba komentowane akty są w dużej mierze zbieżne. Elementy dyferencjujące przyjęte w nich konstrukcje zostaną omówione poniżej.

Zachowuje swoją aktualność twierdzenie, że ani Zasady PECL, ani system DCFR - podobnie jak uprzednio rozważane Reguły UNIDROIT - nie posługują się pojęciem kary umownej. W pierwszej z powołanych regulacji odpowiednik jest $\mathrm{w}$ istocie terminologicznie tożsamy $\mathrm{z}$ tym występującym $\mathrm{w}$ art. 7.4 .13 pkt 1 UPICC, tzn. agreed payment for non-performance, a powinien być rozumiany

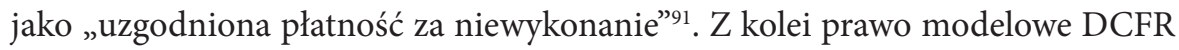
posługuje się terminem stipulated payment for non-performance ${ }^{92}$, tłumaczonym jako „zastrzeżona płatność za niewykonanie”. Podobnie zresztą jak w przypadku art. 7.4.13 UPICC, również względem regulacji z art. 9:509 PECL i art. III-3:712

88 Szerzej zob. J. Jastrzębski, Nietypowe kary umowne - swoboda sankcji kontraktowych i ochrona dłużnika, „Przegląd Prawa Handlowego” 2014, nr 6, s. 11 i n.

89 Zob. Reguły UNIDROIT, art. 7.4.13, s. 289.

90 Zob. w szczególności W. Popiołek, Komentarz do art. 484 [w:] Kodeks cywilny, t. II, Komentarz. Art. 450-1088, red. K. Pietrzykowski, Warszawa 2018, nb. 6.

91 Zob. art. 9:509 pkt 1 PECL; zgodnie z tym przepisem: Where the contract provides that a party who fails to perform is to pay a specified sum to the aggrieved party for such nonperformance, the aggrieved party shall be awarded that sum irrespective of its actual loss.

92 Zob. art. III-3:712 pkt 1 DCFR, zgodnie z którym: Where the terms regulating an obligation provide that a debtor who fails to perform the obligation is to pay a specified sum to the creditor for such non-performance, the creditor is entitled to that sum irrespective of the actual loss. 
DCFR zasadne jest twierdzenie, że syntetyczność tych regulacji w pełni odpowiada współczesnym wymogom wynikającym z realiów międzynarodowego obrotu handlowego.

Zgodnie z treścią art. 9:509 pkt 1 PECL: jeżeli zgodnie z umową strona, która nie spełnia świadczenia, zobowiązana jest $z$ tego tytułu zapłacić określona sume poszkodowanemu, suma ta należy się wierzycielowi bez względu na wysokość faktycznie poniesionej szkody [wyróżnienie - A.M.J.] ${ }^{93}$. Komentowany przepis nie różni się więc znacząco od regulacji, która została wyrażona art. 7.4.13 pkt 1 UPICC. Można wręcz stwierdzić, że podstawowe założenia w skali globalnej (tj. Reguły UNIDROIT) zostały w tej materii recypowane na grunt europejskiego prawa modelowego. Większość komentarzy poczynionych w odniesieniu do art. 7.4.13 UPICC pozostaje więc aktualna także względem art. 9:509 PECL.

Odmiennie sytuacja przedstawia się w przypadku analizowania projektu Wspólnej Ramy Odniesienia. W treści art. III-3:712 ust. 1 DCFR zastrzeżono bowiem, że: jeżeli zgodnie z warunkami regulujacymi zobowiązanie dłużnik, który nie spełnia zobowiązania, zobowiązany jest $z$ tego tytułu zapłacić określona sume wierzycielowi, wierzyciel jest uprawniony do tej sumy bez względu na wysokość faktycznie poniesionej szkody [wyróżnienie - A.M.J.] ${ }^{94}$. Warto zauważyć, że zasadniczym pojęciem, którym posługują się twórcy DCFR, nie jest już występująca w Regułach UNIDROIT i Zasadach PECL „umowa”, ale znacznie szersze

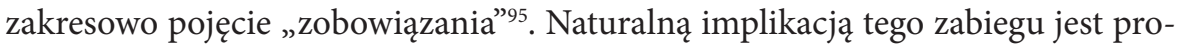
porcjonalne poszerzenie zakresu przedmiotowego DCFR w porównaniu z jego normatywnymi „poprzednikami”"96.

Z uwagi na leksykalną zbieżność występującą w odniesieniu do regulacji kary umownej we wszystkich trzech powołanych aktach prawa modelowego, brak jest

93 M.A. Zachariasiewicz, J. Bełdowski, Europejskie prawo umów. Principles of European Contract Law. Les principes du droit europeen des contrats. Zasady europejskiego prawa umów (tłum. z jęz. angielskiego i francuskiego), cz. I i II, „Kwartalnik Prawa Prywatnego" 2004, nr 3, s. 814 i n.; a także zob. J. Bełdowski, A. Kozioł, Principles of European Contract Law, part III. Les principes du droit europeen du contrat, partie III (Zasady europejskiego prawa umów, część III), „Kwartalnik Prawa Prywatnego”2006, nr 3, s. 860 i n.

Zob. P. Widerski, Charakter prawny kary, op. cit., s. 15.

95 Podobnie zob. P. Machnikowski, T. Pajor, Prawo prywatne w Unii Europejskiej, op. cit., s. 311-312.

96 Całość aktu liczy obecnie X Ksiąg, a więc o 7 więcej, niż było to w przypadku Zasad PECL. DCFR obejmuje bowiem nie tylko prawo kontraktów, ale także kwestie negotiorum gestio, czynów niedozwolonych, bezpodstawnego wzbogacenia, zabezpieczenia na ruchomościach, przeniesienia własności ruchomości czy powiernictwa. Zwraca się także uwagę na istotne znaczenie pojęcia „Czynności prawnej” (art. II-1:101 DCFR). Dokonano wyraźnego oddzielenia części ogólnej od szczegółowej prawa zobowiązań - zob. szerzej P. Machnikowski, T. Pajor, Prawo prywatne w Unii Europejskiej, op. cit., s. 312. 
przeszkód do uznania, że komentarze autorów Reguł UNIDROIT znajdą zastosowanie również i w tych przypadkach ${ }^{97}$. Tym samym agreed/stipulated payment będzie - w zależności od przyjętego przez strony wariantu - realizowała albo funkcję surogatu odszkodowania z tytułu niewykonania (nienależytego wykonania) zobowiązania, albo będzie zastrzeżeniem represyjno-prewencyjnym, zmierzającym do zapewnienia realnego wykonania zobowiązania ${ }^{98}$. Zakres obu pojęć jest w tym wypadku szeroki.

Zarówno art. 9:509 PECL, jak i art. III-3:712 DCFR pozostają zbieżne z regulacją art. $483 \$ 2$ k.c. w zakresie przysługującego dłużnikowi facultas alternativa co do wyboru między zapłatą kary umownej a wykonaniem zobowiązania, nie przewidując takiej możliwości. Oba akty wypowiadają się w sprawie non-performance, $\mathrm{tj}$. niewykonania, a nie alternative performance, $\mathrm{tj}$. alternatywnego wykonania zobowiązania99.

Różnica po raz kolejny pojawia się względem przedmiotu umowy - zarówno Reguły UNIDROIT, jak i Zasady PECL posługiwały się pojęciem „świadczenia”. Prawo modelowe DCFR posługuje się w tym zakresie terminem „zobowiązania”. Żaden z tych aktów nie wprowadza znanej w polskim prawie prywatnym delimitacji, o której mowa w art. $483 \$ 1$ k.c., który statuuje karę umową wyłącznie względem zobowiązań o charakterze niepieniężnym. Cechą spójną dla wszystkich powołanych wyżej regulacji jest z kolei modalne określenie przedmiotu kary konwencjonalnej jako specified sum. Nie ma więc przeszkód, by w „podstawowej” postaci agreed payment zostało wyrażone przez zryczałtowaną sumę, należną wierzycielowi na skutek niewykonania lub nienależytego wykonania tak zobowiązania, jak i pojedynczego obowiązku. W postaci „kwalifikowanej” określenie wysokości kary umownej może nastąpić przez odwołanie się do jakiegoś obiektywnego wskaźnika, pozwalającego na ustalenie określonej sumy w konkretnych okolicznościach ${ }^{100}$. Aktualne pozostają także poczynione względem Reguł UNIDROIT i Zasad PECL ustalenia co do określenia przez strony granic odpowiedzialności dłużnika, w tym w ramach umownego rozszerzenia tej odpowiedzialności ${ }^{101}$.

Również wyróżniane w polskiej doktrynie kary umowne alternatywne i zaliczalne zachowują znaczenie w przypadku sięgania do reguł europejskiego prawa modelowego. Zarówno bowiem PECL, jak i DCFR dopuszczają możliwość zastrzeżenia oznaczonej, minimalnej kwoty kary wadialnej. Wierzyciel będzie mógł oczywiście uzyskać większą kwotę zaspokojenia, jeśli tylko udowodni, że

97 Tak też P. Widerski, Charakter prawny kary, op. cit., s. 16.

98 Ibidem.

99 Tak też Ch. von Bar, E. Clive, H. Schulte-Nölke, Principles, Definitions and Model Rules, op. cit., s. 963.

100 Zob. P. Widerski, Charakter prawny kary, op. cit., s. 36.

101 Ibidem. 
poniesione przez niego straty przekraczają umówioną kwotę minimalną ${ }^{102}$. Pytanie można postawić odnośnie do tego, jaką formę powinno przyjąć „wyrównanie" wysokości kary umownej zastrzeżonej poniżej faktycznie doznanej straty w sytuacji, gdy umówiona między stronami kara konwencjonalna miałaby zostać oszacowana przez zastosowanie obiektywnych wskaźników, dozwalających na precyzyjne wskazanie jej wysokości. W takiej sytuacji można prima facie przyjąć, że nastąpi to albo przez dopłatę oznaczonej kwoty zmierzającej do pokrycia różnicy między sumą zastrzeżoną jako kara umowna przez zastosowanie wskaźnika obiektywnego a rzeczywiście poniesioną przez wierzyciela stratą. Drugim sposobem mógłby okazać się albo wybór innego wskaźnika, albo jednoczesne zastosowanie dodatkowego wskaźnika w celu wyrównania rzeczywiście poniesionej straty. Byłby to więc - utrzymując przyjętą przeze mnie konwencję terminologiczną - mechanizm odwróconego miarkowania. Wątpliwości te można jednak uczynić, w mojej ocenie, bezprzedmiotowymi, konstruując „wskaźnik kaskadowy", a więc następujący jeden po drugim aż do pokrycia straty, z jednoczesnym zachowaniem ogólnych ograniczeń swobody umów.

Kary umowne zastrzegane w zgodzie z „poszerzoną” wersją prawa modelowego DCFR mogą być także wprowadzane do kontraktu na wypadek niewykonania lub wykonania w sposób nienależyty przez dłużnika zobowiązania pozaumownego $^{103}$, co jest stanowiskiem powszechnie aprobowanym również w polskiej doktrynie i judykaturze względem art. 483-484 k.c. ${ }^{104}$.

\section{Podsumowanie}

W toku powyższych rozważań zbadano zjawisko postępującej harmonizacji prawa prywatnego, analizując w tym kontekście założenia wynikające $\mathrm{z}$ tzw. prawa modelowego, a następnie dokonano szczegółowego wskazania praktycznego oddziaływania tychże norm na reguły przyjęte w prawie krajowym (tu: polskim).

102 Zob. O. Lando, H. Beal, The Principles of European Contract Law. Part I: Performance, Non-Performance and Remedies, Dordrecht 1995, s. 454 (w odniesieniu do PECL); także Ch. von Bar, E. Clive, H. Schulte-Nölke, Principles, Definitions and Model Rules, op. cit., s. 962 (w odniesieniu do DCFR).

103 Zob. Ch. von Bar, E. Clive, H. Schulte-Nölke, Principles, Definitions and Model Rules, op. cit., s. 962.

104 Zob. w szczególności W. Borysiak, Komentarz do art. 483 KC [w:] Kodeks cywilny. Komentarz, t. IIIA, Zobowiązania. Cześśc ogólna, red. K. Osajda, Warszawa 2017, nb. 31, 51; P. Drapała, A. Olejniczak, Dodatkowe zastrzeżenia, op. cit., s. 1140-1141; Z. Radwański, A. Olejniczak, Zobowiazzania, op. cit., s. 334-335; A. Rzetecka-Gil, Komentarz do art. 483 KC [w:] Kodeks cywilny. Zobowiązania. Część ogólna. Komentarz, red. A. Rzetecka-Gil, Warszawa 2011, nb. 9; K. Zagrobelny, Komentarz do art. 483, op. cit., s. 902; zob. także wielokrotnie powoływaną uchwałę SN (7) z 6 listopada 2003 r., sygn. akt III CZP 61/03, Legalis. 
Przeprowadzone badania komparatystyczne doprowadziły do sformułowania kilku istotnych wniosków. Po pierwsze, współczesna legislatywa ustawodawstw krajowych w coraz mniejszym stopniu może istnieć „sama sobie”, a więc w oderwaniu od analogicznych regulacji występujących zarówno w prawie ponadnarodowym, jak i w ustawodawstwach państw obcych. Umiędzynarodowienie stosunków między podmiotami prawa prywatnego sprawia, że prawo krajowe musi przewidywać mechanizmy służące ochronie prawnej uczestników tych stosunków (zwłaszcza w płaszczyźnie zobowiązaniowej), a liczba sytuacji, w których dana sytuacja prawna jest „niezauważalna” przez optykę prawa forum, powinna zostać zdecydowanie zmarginalizowana, czemu, w moim przekonaniu, służy odwoływanie się przez judykaturę do prawa modelowego. Nie należy jednak wniosku tego utożsamiać z postulatem bezkrytycznego powielania instytucji istniejących $\mathrm{w}$ różnych systemach prawnych na potrzeby każdocześnie rozpatrywanej sprawy. Chodzi tu bowiem nie o „identycznośc” rozwiązań przyjętych w danym zakresie, ale o wyposażenie systemu prawa krajowego w „instrumentarium dostosowawcze”, które umożliwiłoby reakcję organu stosującego prawo na pojawienie się w rozpatrywanej przezeń sprawie sytuacji, dla której ramy instytucjonalne fori nie pozostają hermetycznie zamknięte. Po drugie, czerpanie z rozwiązań przyjętych w model law gwarantuje posługiwanie się instrumentarium, które wielokrotnie zostało poddane funkcjonalnej „ofensywie” w systemach prawnych państw, z których wywodzą się „konstruktorzy” rozwiązań iniekowanych do prawa modelowego. Po trzecie, wyposażenie systemu prawa krajowego w „mechanizmy dostosowawcze" znacznie usprawni i uwydatni intensyfikację obrotu gospodarczego przez brak konieczności szczegółowego analizowania postanowień umów czy treści czynności prawnych pod kątem zgodności z analogicznymi odpowiednikami funkcjonalnymi w prawie krajowym, koncentrując się jedynie na wspólnych ramach funkcjonalnych danej instytucji, które wynikałyby chociażby z aktów modelowych. Po czwarte, zawarte w prawie harmonizacyjnym ${ }^{105}$ zasady konstrukcyjne, sposób sformułowania określonych hipotez i dyspozycji normatywnych, związane $\mathrm{z}$ nimi skutki, a wreszcie powiązanie ich $\mathrm{z}$ wieloletnim dorobkiem i tradycją legislacyjną poszczególnych ustawodawstw krajowych i transponowanie do reguł prawa modelowego wyłącznie konsensualnie uzgodnionej treści przepisów - tworzy rozwiązania zdecydowanie bardziej podatne na późniejszą fluktuację stanu prawnego i upraszczające praktykę obrotu międzynarodowego (zwłaszcza handlowego). Rozwiązania te charakteryzować będzie kolokwialne „wszechstronne rozważenie” z uwagi na ich naukową proweniencję (walorem model law jest wszak jego akademicki charakter) i powiązanie ze znajomością przez autorów legistalive history ${ }^{106}$ każdej z rodzimych instytucji.

105 Terminem tym posługuję się synonimicznie względem pojęcia „prawa modelowego”.

106 O legislative history jako czynniku zwiększającym wartość funkcjonalną i poznawczą rozwiązań przyjętych w systemie prawnym zob. szerzej A. Bielska-Brodziak, Po co 
Po piąte i ostatnie - rozwiązania przyjęte w najnowszych projektach aktów modelowych w zakresie kary umownej spotykają się z coraz większą przychylnością zarówno polskiej doktryny prawa prywatnego [stąd wspomniana koncepcja zmiany przesłanek względnych i bezwzględnych powstania obowiązku zapłaty kary umownej, stosunku względem przedmiotu zabezpieczenia (już nie tylko umowa, ale bardziej ogólne „zobowiązanie”; w kontekście kary umownej przychylając się do rozwiązań model law - bez znaczenia powinien stać się także jego pieniężny lub niepieniężny charakter) czy granic miarkowania], jak również orzecznictwa (coraz częstsze odwoływanie się przez Sąd Najwyższy w judykatach do wspólnych europejskich projektów kodyfikacyjnych). Analogicznie wspomniane rozwiązania powinny nabrać także znaczenia dla polskiego prawodawcy w kontekście projektowanych zmian w obowiązującym prawie prywatnym. Przyjęte konstrukcje w zakresie prawa umów (i wciąż obowiązującej tu zasady swobody kontraktowej) nie powinny mieć charakteru nadmiernie usztywniającego (jak np. omówiona wcześniej delimitacja zawarta w art. $483 \$ 1$ k.c.), a pozwalać stronom na w pełni swobodne kształtowanie łączącego je stosunku zobowiązaniowego (w tym również konsekwencji związanych z jego naruszeniem), uwzględniając przy tym konieczność „zgodności” przyjętych inter partes rozwiązań z naturą danego zobowiązania (w zgodzie z art. $353^{1}$ k.c.), jak i zapewniając ochronę wynikającą wyłącznie z ogólnych zasad rządzących prawem cywilnym (o ile oczywiście strony postanowią w ten sposób ukształtować łączący je stosunek obligacyjny). Skoro bowiem współczesne tendencje harmonizacyjne, zmaterializowane w projektach prawa modelowego, zmierzają do zapewnienia stronom dużej swobody i modalności w zakresie kształtowania łączącego je stosunku (umożliwiając np. zastrzeżenie stipulated payment także w odniesieniu do zobowiązań pieniężnych), pożądane byłoby, w mojej ocenie, podejmowanie przez ustawodawcę krajowego działań zmierzających do wywołania tożsamego skutku również w prawie polskim (oczywiście w granicach domniemywanej racjonalności prawodawcy) ${ }^{107}$.

Wszystkie powołane okoliczności wskazują, że pogłębiona współpraca środowiska prawników-akademików europejskich, przyjmująca za cel opracowanie normatywnej odpowiedzi na postępujące tendencje harmonizacyjne i zdecydowanie wzmożoną (w porównaniu $z$ latami poprzednimi) wymianę międzynarodową (osobową, ekonomiczną, handlową itp.) jest szczególnie relewantna w czasach, w których granice państw coraz częściej postrzegane są wyłącznie z perspektywy geograficznej lub historycznej.

prawnikom materiały legislacyjne?, „Radca.pl - Kwartalnik Okręgowej Izby Radców Prawnych w Katowicach" 2017, nr 3(15), s. 23 i n.

107 Oczywiście, zastrzeżenia te zyskują cechę relewantności w tych stosunkach prawa prywatnego, które nie mają waloru stricte konsumenckich. Podzielam tu stanowisko, że z uwagi na specyfikę obrotu konsumenckiego - szeroka modalność stosunków zobowiązaniowych w tzw. formie B2C może mieć miejsce wyłącznie wówczas, gdy względem sytuacji prawnej i majątkowej konsumenta wywołuje skutek pozytywny, tzn. polepszający jego sytuację. 


\section{Bibliografia}

Bełdowski J., Kozioł A., Principles of European Contract Law, part III. Les principes du droit europeen du contrat, partie III (Zasady europejskiego prawa umów, cz. III), „Kwartalnik Prawa Prywatengo" 2006, z. 3.

Bielska-Brodziak A., Po co prawnikom materiały legislacyjne?, „Radca.pl - Kwartalnik Okręgowej Izby Radców Prawnych w Katowicach” 2017, nr 3(15).

Bonell M.J., The UNIDROIT Principles Of International Commercial Contracts And CISG - Alternatives Or Complementary Instruments?, ULR 1996, t. 26.

Borysiak W., Glosa do uchw. SN (7) z 06.11.2003 r., sygn. akt III CZP 61/03, „Monitor Prawniczy" 2007, nr 6.

Borysiak W., Komentarz do art. 483 [w:] Kodeks cywilny. Komentarz, t. IIIA, Zobowiązania. Część ogólna, red. K. Osajda, Warszawa 2017.

Dana A., Miejsce „acquis communautaire” w Konstytucji Rzeczypospolitej Polskiej, „Doctrina. Studia Społeczno-polityczne" 2006-2007, nr 3-4.

Dąbrowa J., Kara umowna [w:] System prawa cywilnego, t. III, cz. 1, Prawo zobowiązań część ogólna, red. Z. Radwański, Warszawa 1981.

Drapała P., Olejniczak A., Dodatkowe zastrzeżenia umowne [w:] System prawa prywatnego, t. 5, Prawo zobowiązań - część ogólna, red. E. Łętowska, Warszawa 2013.

Fuchs B., Lex mercatoria - pojęcie [w:] System prawa handlowego, t. 9, Międzynarodowe prawo handlowe, red. W. Popiołek, Warszawa 2013.

Fuchs B., Reguly Międzynarodowych Kontraktów Handlowych UNIDROIT (UPICC) [w:] System prawa handlowego, t. 9, Międzynarodowe prawo handlowe, red. W. Popiołek, Warszawa 2013.

Gołaczyński J., Prawo prywatne międzynarodowe, Warszawa 2003.

Jagielska M. i in., Prawo właściwe w braku wyboru prawa [w:] System prawa prywatnego, t. 20B, Prawo prywatne międzynarodowe, red. M. Pazdan, Warszawa 2015.

Jagielska M., Szpunar M., Polski przekład Reguł UNIDROIT, „Problemy Prawne Handlu Zagranicznego" 2000, t. 19/20.

Jastrzębski J., Nietypowe kary umowne - swoboda sankcji kontraktowych i ochrona dtużni$k a$, „Przegląd Prawa Handlowego” 2014, nr 6.

Juranek A.M., Kara umowna, wybrane klauzule quasipenalne oraz klauzule indemnifikacyjne w prawie polskim i prawie modelowym. Rozważania de lege lata i de lege ferenda, Katowice 2019.

Kodeks cywilny, t. II, Komentarz. Art. 450-1088, red. K. Pietrzykowski, Warszawa 2018.

Kodeks cywilny, t. II, Komentarz do art. 353-626, red. M. Gutowski, Warszawa 2019.

Kodeks cywilny. Komentarz, red. E. Gniewek, P. Machnikowski, Warszawa 2017.

Kodeks cywilny. Komentarz, t. III/A, Zobowiązania. Część ogólna, red. K. Osajda, Warszawa 2017.

Kodeks cywilny. Zobowiązania. Część ogólna. Komentarz, red. A. Rzetecka-Gil, Warszawa 2011.

Lando O., Beale H., The Principles of European Contract Law. Part I: Performance, Non-Performance and Remedies, Dordrecht 1995. 
Lando O., CISG and Its Followers: A Proposal to Adopt Some International Principles of Contract Law, AJCL 2005, t. 53.

Lemkowski M., Kara umowna w przypadku odstapienia od umowy [w:] Kodeks cywilny, t. II, Komentarz do art. 353-626, red. M. Gutowski, Warszawa 2019.

Łętowska E., Multicentryczność współczesnego systemu prawa i jej konsekwencje, „Państwo i Prawo" 2005, z. 4.

Łętowska E., Multicentryczność współczesnego systemu prawa i wykładnia jej przyjazna [w:] Rozprawy prawnicze: ksiega pamiątkowa Profesora Maksymiliana Pazdana, red. L. Ogiegło, W. Popiołek, M. Szpunar Kraków 2005.

Machnikowski P., Brzozowski A., Unifikacja europejskiego prawa umów. Zasady Europejskiego Prawa Umów (PECL) [w:] System prawa prywatnego, t. 5, Prawo zobowiązań część ogólna, red. K. Osajda, Warszawa 2020.

Machnikowski P., Pajor T., Prawo prywatne Unii Europejskiej i jego wplyw na prawo polskie [w:] System prawa prywatnego, t. 1, Prawo cywilne - część ogólna, red. M. Safjan, Warszawa 2012.

Pazdan M., Rott-Pietrzyk E., Łączniki w normach kolizyjnych [w:] System prawa prywatnego, t. 20B, Prawo prywatne międzynarodowe, red. M. Pazdan, Warszawa 2015.

Pazdan M., Wybór prawa w świetle rozporzązenia Rzym I - analiza szczegółowa [w:] System prawa prywatnego, t. 20B, Prawo prywatne międzynarodowe, red. M. Pazdan, Warszawa 2015.

Popiołek W., Komentarz do art. 472, art. 483, art. 484 [w:] Kodeks cywilny, t. II, Komentarz. Art. 450-1088, red. K. Pietrzykowski, Warszawa 2018.

Popiołek W., Obowiązek przyjęcia dostawy towaru w projekcie „Zasad europejskiego prawa umów" i w Konwencji ONZ o międzynarodowej sprzedaży towarów [w:] W kierunku europeizacji prawa prywatnego. Księga pamiatkowa dedykowana Profesorowi Jerzemu Rajskiemu, red. A. Brzozowski, W. Kocot, K. Michałowska,Warszawa 2007.

Radwański Z., Olejniczak A., Zobowiązania - część ogólna, Warszawa 2014.

Romanowski M., Ogólne reguły wykładni kontraktów w świetle zasad europejskiego prawa kontraktów a reguly wykładni umów w prawie polskim, „Przegląd Prawa Handlowego” 2004.

Rott-Pietrzyk E., Harmonizacja prawa prywatnego w aktach prawa modelowego (soft law) [w:] System prawa handlowego, t. 9, Międzynarodowe prawo handlowe, red. W. Popiołek, Warszawa 2013.

Rott-Pietrzyk E., Interpretacja umów w prawie modelowym i wspólnym europejskim prawie sprzedaży (CESL), Warszawa 2013.

Rozprawy prawnicze: ksiega pamiątkowa Profesora Maksymiliana Pazdana, red. L. Ogiegło, W. Popiołek, M. Szpunar, Kraków 2005.

Rzetecka-Gil A., Komentarz do art. 483 [w:] Kodeks cywilny. Zobowiązania. Część ogólna. Komentarz, red. A. Rzetecka-Gil, Warszawa 2011.

Skąpski J., Autonomia woli w prawie prywatnym międzynarodowym $w$ zakresie zobowiazań z umów, Kraków 1964.

Skowrońska-Bocian E., Kara umowna - kompensacja czy represja?, „Zeszyty Prawnicze UKSW" 2003, nr 3/2. 
System prawa cywilnego, t. III, cz. 1, Prawo zobowiązań - część ogólna, red. Z. Radwański, Warszawa 1981.

System prawa handlowego, t. 9, Międzynarodowe prawo handlowe, red. W. Popiołek, Warszawa 2013.

System prawa prywatnego, t. 1, Prawo cywilne - część ogólna, red. M. Safjan, Warszawa 2012.

System prawa prywatnego, t. 5, Prawo zobowiązań - część ogólna, red. E. Łętowska, Warszawa 2013.

System prawa prywatnego, t. 5, Prawo zobowiązań - część ogólna, red. K. Osajda, Warszawa 2020.

System prawa prywatnego, t. 6, Prawo zobowiązań - część ogólna, red. A. Olejniczak, Warszawa 2018.

System prawa prywatnego, t. 20B, Prawo prywatne międzynarodowe, red. M. Pazdan, Warszawa 2015.

Szumański A., Renegocjacje umów w międzynarodowym obrocie gospodarczym. Studium prawnoporównawcze, Kraków 1994.

Szwaja J., Kara umowna według Kodeksu cywilnego, Warszawa 1967.

Von Bar Ch., Clive E., Schulte-Nölke H., Principles, Definitions and Model Rules of European Private Law. Draft Common Frame of Reference (DCFR), Full Edition, t. I, Munich 2009.

Warkałło W., Wykonywanie zobowiązań i skutki ich niewykonania wedtug Kodeksu cywilnego, „Państwo i Prawo” 1965, z. 8-9.

Widerski P., Charakter prawny kary umownej wedtug prawa polskiego na tle ponadnarodowych uregulowań prawnych, „Studia Prawa Prywatnego” 2018, nr 2.

Wieczorek E., Zasady europejskiego prawa umów, Gdańsk 2005.

W kierunku europeizacji prawa prywatnego. Ksiegga pamiątkowa dedykowana Profesorowi Jerzemu Rajskiemu, red. A. Brzozowski, W. Kocot, K. Michałowska, Warszawa 2007.

Zachariasiewicz M.A., Bełdowski J., Europejskie prawo umów. Principles of European Contract Law. Les principes du droit europeen des contrats. Zasady europejskiego prawa umów (tłum. z jęz. angielskiego i francuskiego), cz. I i II, „Kwartalnik Prawa Prywatnego" 2004, nr 3.

Zagrobelny K., Komentarz do art. 472, art. 483, art. 484 [w:] Kodeks cywilny. Komentarz, red. E. Gniewek, P. Machnikowski, Warszawa 2017.

Zoll F., Pojęcie niewykonania i nienależytego wykonania zobowiązania oraz kwalifikowane postaci naruszenia zobowiązania i ich skutki [w:] System prawa prywatnego, t. 6, Prawo zobowiązań - część ogólna, red. A. Olejniczak, Warszawa 2018. 